\title{
Innovative Development of College English Education from the Perspective of New Media
}

\author{
Cong Wu \\ Sichuan Vocational College of Information Technology, Sichuan 628017, China \\ tracey_wu@163.com
}

Keywords: New media technology; College English; Innovative development.

\begin{abstract}
The development and popularization of Chinese new media has made certain profound effects on education at the same time of influencing people's daily life, which can promote the innovation and development of teaching methods. In order to express the application value of new media technology in Chinese college English teaching, the trend of college English teaching should be analyzed and some innovative ways of teaching must be put forward. Micro course is characteristic of the English education in colleges and universities, continuously promoting the coordination and integration of new media and English education in colleges and universities on the strategies of promoting information and training. This paper illustrated the innovative development of college English education from the perspective of new media.
\end{abstract}

\section{Introduction}

In our country, the concept of new media is more extensive, and the tool of information communication is more common, which is often divided into old media and new media from the aspect of media. We contact the old media in our daily life, and old media includes newspapers and television and other means of communication. New media includes micro-blog, We-Chat and QQ. New media has achieved the integration of information technology and network technology under certain circumstances and it has constantly promoted current English teaching reform in certain conditions. Its information channel is more extensive and the information delivery is diversified, which are popular among college students.

\section{The Application Value of New Media Technology in the Teaching Methods}

The corresponding combination of technology and English teaching strategies in the new media is good for continuously breaking through the limitations in the education so as to realize the initiative of college students learning. Such method can allow students to truly become the master of teaching in daily classroom study, unceasingly promoting the development of students personality to create corresponding harmonious study atmosphere with equal relationship of teachers and students. Twoway interactive teaching mode has been applied under the teaching background of new media. At the same time, the application in teaching mode of the new media can realize the effective teaching interaction and learning between teachers and students to promote students' understanding with related English knowledge to constantly realize their qualities increase of English knowledge application. In the study of new media, the higher harmonious teaching atmosphere can make various English knowledge shared with resources and enhance college students' learning interest. The new media technology should be constantly applied in college teaching classroom practice, which can help college students activate the enthusiasm and the exploratory desire and is more conducive to arousing students' enthusiasm in learning. So the effect of students' classroom activity on the subjectivity can be fully expressed. Different senses of the students can be fully mobilized from the perspective of new media technology. And the integrated application of images, audio and video can motivate their exploratory desires so as to improve the vitality in the teaching classroom and give students a higher sense of experience in English learning. At the same time, English knowledge is characterized by abstract learning in the teaching of different universities. The learning rhythm of 
college students in the classroom is controlled accordingly under the application of new media technology and teaching environment, which is more scientific in their learning mode. In the teaching method of new media, it is not limited by time and space, and it greatly broadens the students' vision on English learning under certain circumstances. At the same time, students can also master the rhythm with extracurricular learning according to their own knowledge and learning situation. What's more, it should also realize the complete development of structure in English knowledge. In fact, students can communicate with teachers and students through QQ and We-Chat in the process of teaching so as to solve the problems related to English knowledge.

\section{The Ideological Trend in the Reform of College English Education Under the Influence of New Media Technology}

The integration of new media and college English teaching reform can solve the traditional teaching modes of singly imparting language knowledge. In college English teaching, continuous application of new media can make corresponding reform in essence. For instance, teachers can regard common social phenomena and topics as the core of related subject discussion. They can fully applied modern teaching resources and Internet to continually guide students to make corresponding discussion and competition of group discussion. And they can make students constantly increase the language learning skills, application and communication ability level. At the same time, it is conducive to strengthen students' cooperation consciousness and competition.

The class teaching is regarded as the expression of teaching contents in traditional college English teaching. And the modern teaching thought of "students oriented" is usually neglected. The channel of learning in class of college student is relatively simple. In this case, new media can be added to the teaching of traditional college English to improve and adjust the classroom teaching. Equal interaction and learning atmosphere among students +teachers +students can be constantly created under some circumstances, in order to promote the trust degree of each other. Such learning atmosphere of freedom and equality can be built in the process of college English teaching, and teachers and students can take advantage of the teaching method of communication, discussion and collaboration to constantly train students' abilities of independent leaning and research abilities on the form of promoting the cooperation and practice. At the same time, teaching will no longer be a process in students' personalized learning but the channel of the common study between students and students, teachers and students. The perfect application with communication technology and Internet technology can help English teachers build a good three-dimensional teaching and multifunctional virtual space of the communication to some extent. The application of this space can help to share the corresponding points and make the activities of language practice between teachers and students through the digitization of information resources sharing.

\section{Current Status of College English Teaching Development}

1. There's no optimization on education

It is impossible to adopt a single teaching method in English teaching, but to constantly use different teaching approaches, which can help the development of English education. It is same in college English teaching. We should constantly optimize the teaching and let the teaching methods in English show different teaching. The biggest characteristics of college English teaching is the teaching way is not enough diversified. It will abstract students to learn if the teaching is added independent and exploratory teaching and purpose. These are the different methods between college English teaching and junior and senior school English teaching. Therefore, we should constantly innovate teaching methods in the teaching process. However, this is not reflected in the teaching process of college English teaching.

2. Irrational English curriculum

With the continuous implementation of education in our country, every university in our country has paid much attention to the personalized development of reform in education. But at present, the school has higher requirements with students' comprehensive English qualities in college English 
teaching. English learning should be not only abundant, but also personalized. But in the practice of English teaching, it is more difficult for the school to formulate relative rationality as well as detailed English teaching goal. There exist irrational problems on the arrangement of curriculum, so it is more impossible to select specific teaching methods based on students' learning conditions. It leads to the various qualities of college students. And the irrational problems existing in the arrangement are bad for students to form a good ideology of the autonomous learning.

\section{The Development Strategy of Education Innovation in English Under New Media Technology}

1. Optimize and integrate learning materials with new media micro-courses

With the support of new media technology in our country, micro-course has gradually emerged and has been paid attention to by corresponding teaching workers. Such method can not only reflect strong interactivity but fast thinking in information transmission and strong participation, adapting to the English education teaching request, and its application will become more extensive. Students have strong curiosity and they are willing to accept new things and more active in the mind. Exactly, micro courses can meet with this kind of learning needs, so it is good for the effective development of teaching activities. Traditional teaching mode is just fixed on the books of knowledge and attaches more importance to the memory of knowledge, which will lead to the dull teaching and students' mental tiredness. But micro-course tends to be combining the teaching with entertainment so as to effectively make up the psychological defects and the insufficiency in certain circumstances, which can provide students with more relaxing and interesting learning atmosphere in English learning and make effect increase of teaching in teaching courses. However, in the current English education, the resources of micro-courses are relatively poor, which is not conducive to the construction of complete knowledge points. And there are problems and deficiencies in the teaching of micro-courses. Therefore, schools and teachers should pay more attention to their ideas and optimizing and integrating resources in teaching. They should properly cut and expand teaching resources in the aid of new media on the integration of teaching content, and integrate materials with teaching characteristics, including local cultural resources and campus English subject. The teaching resources should be effectively used in integrating and optimizing the micro-course content to constantly increase students' learning efficiency.

2. Use new media technology to increase students' learning interest.

Due to the constant integration of chat softwares into the English education activities, they should be more reasonably used in the teaching so as to build a better teaching environment, which is convenient for students to learn and English teachers to teach. Teachers and students, students and students are able to communicate timely and convenient to carry out the activities under the application of chat software. At the same time, for the difficult points students cannot master in class, English teachers can make corresponding explanation and analysis through chat softwares, to activate teaching and learning atmosphere. And teachers can make corresponding learning tracking and timely guidance with students' learning through chat softwares. In addition, it can also break the barrier of the classroom and build a personalized teaching mode, constantly improving and perfecting the contents of the teaching. Among them, QQ group can be used in the teaching, which can constantly improve students' English learning positiveness and enrich teaching contents through English songs and English news. What's more, it can make students understand the different charm of English and the whole class teaching more lively and interesting and students will not feel bored any more.

\section{Conclusion}

To sum up, the application of new media technology to the teaching process can bring some changes to English teaching under certain circumstances. It also facilitates students' access to information resources, which is conducive to stimulate students' interests and enthusiasm in learning English. Meanwhile, they should more conform to this trend of thought, combined with the specific teaching needs and take more effective measures to innovate new English education. 


\section{Acknowledgements}

Research on classroom mode of initiaative-cooperative learning in vocational English teaching based on teaching experience in America. Supported by Sichuan vocational college of information technology (Grant No 2016(9)).

\section{References}

[1]. Liang Zhao. Research on the innovative development path of college English teaching from the perspective of new media[J]. Young life, 2018(02):12.

[2]. Tao Guo. Research on the innovative development path of college English teaching from the perspective of new media[J]. Modern communication,2017(21):130.

[3]. Chuanwei Zhang. Research on the innovative development path of college English teaching from the perspective of new media[J]. Comparative study on cultural innovation,2017,1(28):84+86.

[4]. Yiye Wang. Innovative development countermeasures of English teaching from the perspective of new media[J]. Journal of higher education,2016(05):113-114.

[5]. Sisi Ran. Innovative development of college English teaching from the perspective of new media[J]. The news front,2015(09):147-148. 